\title{
Genetic diversity in Coffea canephora genotypes for leaf nutrient concentration
}

\section{Diversidad genética en genotipos de Coffea canephora para la concentración de nutrientes en la hoja}

Cleidson Alves da Silva ${ }^{1}$, Eileen Azevedo Santos ${ }^{2}$, Alexandre Pio Viana ${ }^{2}$, Jairo Rafael Machado Dias ${ }^{3}$, Fábio Luiz Partelli ${ }^{4}$

Originales: Recepción: 18/05/2020 - Aceptación: 12/02/2021

\begin{abstract}
This study analyzed the genetic diversity in Coffea canephora genotypes by univariate and multivariate statistical analysis, based on concentrations of macro- and micronutrients in coffee leaves in the stages of pre-flowering and grain filling. The experiment was arranged in randomized blocks with three replications, in a $42 \times 2$ factorial design, in which factor one represented the evaluated genotypes and factor two the periods of leaf sampling, i.e., pre-flowering and grain filling. The data of leaf nutrient concentrations were subjected to analysis of variance by the F test $(\mathrm{p}<0.01)$, and genetic parameters were estimated. For the study of genetic diversity, the genotypes were grouped by the hierarchical unweighted pair-group method using arithmetic averages (UPGMA). The relative importance of a trait to predict genetic diversity was also studied. There is genetic divergence for leaf nutrient concentration in C. canephora genotypes. With a maximum limit of $60 \%$ of dissimilarity between genotypes, four groups were also formed by UPGMA. For the 42 evaluated genotypes, leaf S concentration was the most important trait for genetic diversity; this genotypic variability should be investigated to enhance the efficiency of nutritional diagnosis.
\end{abstract}

\section{Keywords}

Conilon coffee $\bullet$ sampling period $\bullet$ mineral nutrition $\bullet$ multivariate analysis

1 Universidade Federal de Lavras. Department of Agriculture. Lavras. Minas Gerais. Brazil. cleydson91@gmail.com

2 Universidade Estadual do Norte Fluminense Darcy Ribeiro. Laboratory of Genetics and Plant Breeding. Campos dos Goytacazes. Rio de Janeiro. Brazil.

3 Universidade Federal de Rondônia. Department of Agronomy. Rolim de Moura. Rondônia. Brazil.

4 Universidade Federal do Espírito Santo. Department of Agrarian and Biological Sciences. São Mateus. Espírito Santo. Brazil. partelli@yahoo.com.br 


\section{RESUMEN}

Este estudio analizó la diversidad genética en los genotipos de Coffea canephora mediante análisis estadístico univariado y multivariado, basado en las concentraciones de macro y micronutrientes en las hojas de café en las etapas de pre-floración y llenado de granos. El experimento se organizó en bloques aleatorios con tres repeticiones, en un diseño factorial de $42 \times 2$, donde el factor uno representaba los genotipos evaluados y el factor dos los períodos de muestreo de hojas, es decir, pre-floración y llenado de granos. Los datos de las concentraciones nutricionales de las hojas se sometieron a un análisis de varianza mediante la prueba $\mathrm{F}(\mathrm{p}<0,01)$, y se estimaron los parámetros genéticos. Para el estudio de la diversidad genética, los genotipos se agruparon por el método jerárquico de pares de grupos no ponderados, utilizando medios aritméticos (UPGMA). También se ha estudiado la importancia relativa de un rasgo para predecir la diversidad genética. Existe divergencia genética para la concentración de nutrientes en las hojas en los genotipos de C. canephora. Con un límite máximo del 60\% de disimilitud entre los genotipos, el método UPGMA formó cuatro grupos. Para los 42 genotipos evaluados, la concentración de S en las hojas fue la característica más importante para la diversidad genética. La variabilidad genotípica debe investigarse para mejorar la eficiencia del diagnóstico nutricional.

Palabras clave

Café conilon • periodo de muestreo $\bullet$ nutrición mineral • análisis multivariante

\section{INTRODUCTION}

Two species of the genus Coffea are commercially produced, i.e., C. arabica and C. canephora. Brazil is the world's largest coffee producer, and in the last 10 years, C. canephora yields have increased over 90\% (6). Among the technologies applied to raise yields, e.g., irrigation, superior genotypes, higher planting density and phytosanitary control (23), an appropriate nutritional management is also relevant (35).

The nutritional status of plants can be determined by the nutrient content in plant tissues, and the leaves are physiologically active organs that are used for the nutritional diagnosis. A correct interpretation of the leaf analysis is a fundamental tool for an adequate supply of nutrients in coffee plantations. To this end, reference values such as critical levels and sufficiency ranges are used $(30,34,35)$. However, these reference values to determine the nutritional status do not take the genetic diversity for leaf nutrient concentrations in Conilon coffee genotypes into account, which is an inherent feature of self-incompatible allogamous species (19).

The high genetic variability in Conilon coffee allows the identification of plants with different characteristics within the species $(17,18,28)$. The genotypes used in commercial crops differ from each other in nutrient and dry matter accumulation $(24,33)$, vegetative growth (32) and nutrient uptake and use efficiency $(2,26,27)$. Thus, genotypic variation is one of the main factors causing differences in species nutrition (10).

Multivariate analysis is a technique that has been widely used to quantify genetic divergence and allows integrating the multiple information of a set of traits extracted from experimental units. This increases the possibilities of choosing divergent parents in breeding programs (15). For the study of genetic diversity in C. canephora, multivariate approaches have been used to evaluate morpho-agronomical $(17,22)$, morphological $(7)$ and leaf morpho-anatomical traits (18).

Since nutrient uptake, transport and redistribution in plants are genetically controlled, genotypes can be improved and/or selected for a more efficient nutrient use (16), using multivariate techniques as analysis method. Thus, the characterization of genetic variability for leaf nutrient concentration in C. canephora species may contribute to more accurate diagnoses of the nutritional management of the crop and generate important information for the planning of breeding programs.

The hypothesis of the work is that the genotypes have different concentrations of nutrients in the leaves, contributing to the genetic variability of the species $C$. canephora. 
Therefore, the objective of this study was to identify the genetic diversity of coffee leaf concentrations of macro- and micronutrients in the phenological stage of pre-anthesis and grain filling in $C$. canephora genotypes by univariate and multivariate statistical analysis.

\section{MATERIAL AND METHODS}

The experiment was conducted on a rural property in northern Espírito Santo $\left(18^{\circ} 39^{\prime}\right.$ $43^{\prime \prime} \mathrm{S}, 40^{\circ} 25^{\prime} 52^{\prime \prime} \mathrm{W}$; 199 masl) where the mean annual temperature is $23^{\circ} \mathrm{C}$. According to Köppen, the predominant climate in the region is Aw (tropical with a dry season) (1). The soil at the site is a Latossolo Vermelho-Amarelo, distrófico, with clayey texture and a wavy relief (38). The chemical and physical characteristics are described in table 1.

Table 1. Chemical and granulometric analysis of soil in the experimental area. Nova Venécia, ES - Brazil.

Tabla 1. Análisis químico y granulométrico del suelo en el área experimental. Nova Venécia, ES - Brasil.

\begin{tabular}{|c|c|c|c|c|c|c|}
\hline \multirow{2}{*}{ Chemical attributes } & \multicolumn{6}{|c|}{ Depth (cm) } \\
\hline & 0-10 & $10-20$ & $20-30$ & $30-40$ & $40-50$ & $50-60$ \\
\hline $\mathrm{K}\left(\mathrm{mg} \mathrm{dm}^{-3}\right)$ & 110 & 95 & 74 & 57 & 52 & 46 \\
\hline $\mathrm{S}\left(\mathrm{mg} \mathrm{dm}^{-3}\right)$ & 15 & 11 & 29 & 15 & 15 & 17 \\
\hline $\mathrm{Ca}\left(\mathrm{cmol} \mathrm{dm}^{-3}\right)$ & 3.8 & 3.4 & 1.9 & 1 & 0.7 & 0.6 \\
\hline $\operatorname{Mg}\left(\mathrm{cmol} \mathrm{dm}^{3}\right)$ & 1 & 0.9 & 0.4 & 0.3 & 0.1 & 0.1 \\
\hline $\mathrm{Al}\left(\mathrm{cmol} \mathrm{dm}^{-3}\right)$ & 0 & 0 & 0.3 & 0.7 & 0.8 & 0.8 \\
\hline $\mathrm{H}+\mathrm{Al}$ & 1.6 & 1.8 & 2.4 & 2.9 & 3.1 & 3.1 \\
\hline $\mathrm{pH}-\mathrm{H}_{2} \mathrm{O}$ & 6.6 & 6.5 & 5.3 & 4.8 & 4.8 & 4.8 \\
\hline Organic matter (dag $\mathrm{dm}^{-3}$ ) & 2.1 & 1.7 & 1.1 & 0.8 & 0.7 & 0.5 \\
\hline $\mathrm{Fe}\left(\mathrm{mg} \mathrm{dm}^{-3}\right)$ & 140 & 138 & 126 & 94 & 88 & 87 \\
\hline $\mathrm{Zn}\left(\mathrm{mg} \mathrm{dm}^{-3}\right)$ & 10.2 & 4.5 & 2.9 & 1.1 & 0.6 & 0.5 \\
\hline $\mathrm{Cu}\left(\mathrm{mg} \mathrm{dm}^{-3}\right)$ & 3.4 & 4.3 & 3 & 1.9 & 1.2 & 1 \\
\hline $\mathrm{Mn}\left(\mathrm{mg} \mathrm{dm}^{-3}\right)$ & 207 & 174 & 104 & 46 & 44 & 40 \\
\hline $\mathrm{B}\left(\mathrm{mg} \mathrm{dm}^{-3}\right)$ & 0.81 & 0.83 & 0.58 & 0.55 & 0.56 & 0.61 \\
\hline $\mathrm{Na}\left(\mathrm{mg} \mathrm{dm}^{-3}\right)$ & 11 & 37 & 8 & 6 & 5 & 4 \\
\hline \multicolumn{7}{|l|}{ Granulometry $\left(\mathrm{g} \mathrm{kg}^{-1}\right)$} \\
\hline Sand & 434 & 352 & 188 & 368 & 366 & 376 \\
\hline Silt & 86 & 168 & 212 & 32 & 74 & 124 \\
\hline Clay & 480 & 480 & 600 & 600 & 560 & 500 \\
\hline
\end{tabular}

In 2014, Conilon coffee was planted, consisting of 42 C. canephora genotypes, grown under full sun, in rows spaced $3 \mathrm{~m}$ and plants spaced $1 \mathrm{~m}$ apart, i.e., at a plant density of 3333 plants per hectare. The cultural treatments were applied according to the technical guidelines for the crop, basically with herbicide weed control and manual cutting, preventive phytosanitary management, liming, fertilization and drip irrigation.

The treatments received 500,100, and $400 \mathrm{~kg} \mathrm{ha}^{-1}$ year-1 of $\mathrm{N}, \mathrm{P}_{2} \mathrm{O}_{5}$, and $\mathrm{K}_{2} \mathrm{O}$, respectively, applied depending on plant requirements and phenological stages. Soil micronutrients were corrected by applying $2 \mathrm{~kg} \mathrm{ha}^{-1}$ year $^{-1} \mathrm{Zn}, 1.0 \mathrm{~kg} \mathrm{ha}^{-1}$ year $^{-1} \mathrm{~B}, 2.0 \mathrm{~kg} \mathrm{ha}^{-1}$ year $^{-1} \mathrm{Cu}$, and $10 \mathrm{~kg} \mathrm{ha}^{-1}$ year $^{-1} \mathrm{Mn}$.

The experiment was arranged in randomized blocks with three replications, in a 42x2 factorial design, in which factor one represented the evaluated genotypes (table 2, page 25) and factor two the sampling periods (pre-flowering and grain filling). Each experimental plot consisted of seven plants, considering the five central plants for evaluation. 
Table 2. Identification of 42 Coffea canephora genotypes. Nova Venécia, ES - Brazil.

Tabla 2. Identificación de 42 genotipos de Coffea canephora. Nova Venécia, ES - Brasil.

\begin{tabular}{|c|c|c|c|c|c|}
\hline Code & Name & Code & Name & Code & Name \\
\hline 1 & Verdim R & 15 & Bamburral & 29 & Tardio C \\
\hline 2 & B01 & 16 & Pirata & 30 & A1 \\
\hline 3 & Bicudo & 17 & Peneirão & 31 & Cheique \\
\hline 4 & Alecrim & 18 & Z39 & 32 & P2 \\
\hline 5 & 700 & 19 & Z35 & 33 & Emcapa 02 \\
\hline 6 & CH1 & 20 & Z40 & 34 & Emcapa 153 \\
\hline 7 & Imbigudinho & 21 & Z29 & 35 & P1 \\
\hline 8 & AD1 & 22 & Z38 & 36 & LB1 \\
\hline 9 & Graudão HP & 23 & Z18 & 37 & 122 \\
\hline 10 & Valcir P & 24 & Z37 & 38 & Verdim D \\
\hline 11 & Beira Rio 8 & 25 & Z21 & 39 & Emcapa 143 \\
\hline 12 & Tardio V & 26 & Z36 & 40 & Ouro negro 1 \\
\hline 13 & AP & 27 & Ouro Negro & 41 & Ouro negro 2 \\
\hline 14 & L80 & 28 & 18 & 42 & Clementino \\
\hline
\end{tabular}

Genotype 33 belongs to cv. Emcapa 8111 and genotypes 34 and 39 to cv. Emcapa 8131 (4). Genotypes 1, 11, 15, 16 and 30 belong to cv. Tributun $(18,37)$ and 30 and 35 to cv. Andina $(28,36)$.

In June, coffee leaf samples were collected in the pre-flowering period and in December during grain filling. In both periods, leaf samples were collected on either side of each tree, from the middle third of the plant, taking the third or fourth pair of leaves from the apex of the plagiotropic branches. The leaves were placed in paper bags and dried in a forced air circulation oven at $65^{\circ} \mathrm{C}$ to constant weight.

The collected material was sent to a plant tissue analysis laboratory to determine the leaf concentrations of nitrogen $(\mathrm{N})$, phosphorus $(\mathrm{P})$, potassium $(\mathrm{K})$, calcium $(\mathrm{Ca})$, magnesium $(\mathrm{Mg})$, sulfur $(\mathrm{S})$, iron. $(\mathrm{Fe})$, zinc $(\mathrm{Zn})$, copper $(\mathrm{Cu})$, manganese $(\mathrm{Mn})$ and boron $(\mathrm{B})$, according to the methodology described by Silva (2009).

The values for leaf nutrient concentration were subjected to analysis of variance by the $F$ test $(p<0.01$ ) for each trait separately to detect genetic variation between the genotypes. For the leaf concentration of each nutrient, the coefficient of experimental variation (CVe), coefficient of genetic variation $(\mathrm{CVg})$ and coefficient of genotypic determination $\left(\mathrm{H}^{2}\right)$ were estimated. The Scott Knott algorithm ( $\leq \leq 0.05$ ) was used to group the genotypes according to the mean leaf nutrient concentrations.

For the study of genetic diversity, Mahalanobis' generalized distance matrix $\left(\mathrm{D}^{2}\right)$ was established as similarity measure and the genotypes were grouped by the Unweighted Pair Group Method using Arithmetic Means (UPGMA). The study of the relative importance of leaf nutrient concentrations to predict genetic diversity was also applied, as proposed by Singh (1981). All statistical analyses were performed using Genes software (8).

\section{RESULTS AND DISCUSSION}

According to the analysis of variance, the differences in leaf concentration of all nutrients between the evaluated periods and genotypes were significant at $1 \%$ and $5 \%$ probability by the F test, except for Zn, which was not significant for either source of variation (table 3, page 26). Significant interactions between evaluated periods and genotypes were only observed for $\mathrm{Ca}, \mathrm{S}$ and $\mathrm{Cu}$. The significant results indicate differentiated responses of the evaluated genotypes, suggesting the existence of variability in leaf nutrient concentrations, which makes studies related to genetic diversity possible. 
Table 3. Summary of variance analysis, estimates of experimental coefficient of variation (CVe), coefficient of genetic variation (CVg) and coefficient of genotypic determination $\left(\mathrm{H}^{2}\right)$ for leaf concentration of macro- and micronutrients in 42 Coffea canephora genotypes during pre-flowering and grain filling. Nova Venécia, ES - Brazil.

Tabla 3. Resumen del análisis de varianza, estimaciones del coeficiente de variación experimental (CVe), coeficiente de variación genética (CVg) y coeficiente de determinación genotípica $\left(\mathrm{H}^{2}\right)$ para la concentración foliar de macro y micronutrientes en 42 genotipos de Coffea canephora durante la floración previa y relleno de grano. Nova Venécia, ES - Brasil.

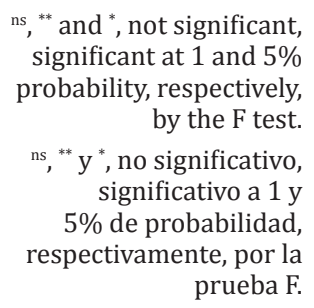

\begin{tabular}{|c|c|c|c|c|c|c|c|c|}
\hline \multirow{2}{*}{ Nutrients } & \multicolumn{4}{|c|}{ Mean square } & \multirow{2}{*}{ Mean } & \multirow{2}{*}{$\begin{array}{l}\text { CVe } \\
\text { (\%) }\end{array}$} & \multirow{2}{*}{$\begin{array}{l}\text { CVg } \\
(\%)\end{array}$} & \multirow{2}{*}{$\begin{array}{l}\mathrm{H}^{2} \\
(\%)\end{array}$} \\
\hline & Stage (St) & Genotypes (G) & St $\times$ G & Error & & & & \\
\hline $\mathrm{N}$ & $724.71^{* *}$ & $5.47^{*}$ & $2.47^{\mathrm{ns}}$ & 3.23 & 26.63 & 6.75 & 2.29 & 40.81 \\
\hline $\mathrm{P}$ & $2.11^{* *}$ & $0.02^{* *}$ & $0.01^{\mathrm{ns}}$ & 0.01 & 1.08 & 8.39 & 4.71 & 65.41 \\
\hline $\mathrm{K}$ & $1352.42^{* *}$ & $7.26^{* *}$ & $3.50^{\text {ns }}$ & 2.81 & 11.63 & 14.42 & 7.40 & 61.23 \\
\hline $\mathrm{Ca}$ & $1067.45^{* *}$ & $32.14^{* *}$ & $16.72^{* *}$ & 8.33 & 18.34 & 15.73 & 10.85 & 74.07 \\
\hline $\mathrm{Mg}$ & $290.87^{* *}$ & $5.73^{* *}$ & $1.42^{\mathrm{ns}}$ & 1.32 & 5.86 & 19.58 & 14.61 & 76.96 \\
\hline$S$ & $10.50^{* *}$ & $0.70^{* *}$ & $0.16^{* *}$ & 0.08 & 2.05 & 14.13 & 15.72 & 88.12 \\
\hline $\mathrm{Fe}$ & $35145.14^{* *}$ & $638.16^{* *}$ & $402.20^{\mathrm{ns}}$ & 282.11 & 90.65 & 18.52 & 8.49 & 55.79 \\
\hline $\mathrm{Zn}$ & $6.34^{\mathrm{ns}}$ & $4.93^{\mathrm{ns}}$ & $4.32^{\mathrm{ns}}$ & 3.53 & 7.79 & 24.11 & 6.19 & 28.39 \\
\hline $\mathrm{Cu}$ & $80.01^{* *}$ & $36.13^{* *}$ & $17.35^{* *}$ & 8.06 & 16.21 & 17.51 & 13.33 & 77.67 \\
\hline $\mathrm{Mn}$ & $4053847.00^{* *}$ & $76890.91^{* *}$ & $22610.86^{\text {ns }}$ & 31852.94 & 596.43 & 29.92 & 14.52 & 58.57 \\
\hline B & $5040.19^{* *}$ & $489.81^{* *}$ & $110.32^{\text {ns }}$ & 92.93 & 63.25 & 15.24 & 12.85 & 81.02 \\
\hline
\end{tabular}

For most leaf concentrations, the experimental coefficient of variation (CVe) was $<20 \%$, which is an acceptable value for experiments with perennial crops such as coffee (11). The lowest leaf concentration was that of $\mathrm{N}$ and the highest of $\mathrm{Mn}$, which suggests the lowest environmental influence on $\mathrm{N}$ and the highest on $\mathrm{Mn}$ (table 3). Lower CVe values for leaf concentration of $\mathrm{N}$ and higher values for Mn were also found by Partelli et al. $(2007,2016$, 2018) and Gomes et al. (2016), who evaluated the leaf concentration of these nutrients during pre-flowering and grain filling.

Leaf concentrations from $2.29 \%$ for $\mathrm{N}$ to $15.72 \%$ for S were observed for the coefficient of genetic variation (CVg) (table 3). This is an important parameter that allows conclusions about the range of variability contained in the population for different traits, allowing a comparison of the levels of genetic variability in different genotypes (11). Since the parameter is directly linked to genetic variability, it can provide breeders with an idea of the relative magnitude of changes accessible by selection (14).

Considering the genotype effect as fixed, the genotypic coefficient of determination $\left(\mathrm{H}^{2}\right)$, i.e., the limit of heritability, was estimated at $28.39 \%$ for $\mathrm{Zn}$ (minimum), and $88.12 \%$ for $\mathrm{S}$ (maximum). Values of $\mathrm{H}^{2}$ close to $100 \%$ indicate a high genetic control for the traits in question, along with a low environmental influence (table 3). Together with $\mathrm{S}$, the leaf concentrations of $\mathrm{Cu}$ and $\mathrm{Mg}$ were the highest for $\mathrm{H}^{2}$. Evaluating macronutrient concentrations in plant tissues of a C. canephora genotype, Starling et al. (2019) also observed that the $\mathrm{S}$ and $\mathrm{Mg}$ concentrations stood out among the macronutrients with highest $\mathrm{H}^{2}$ values.

During grain filling, the leaf concentrations of the macronutrients $\mathrm{N}, \mathrm{P}$ and $\mathrm{K}$ of the genotypes were $13.59 \%, 18.18 \%$ and $49.67 \%$ higher, respectively, than in the pre-flowering period (table 4, page 27). These results agree with those of Partelli et al. $(2016 ; 2018)$, in that the leaf concentrations of N, P and $\mathrm{K}$ are higher during grain filling. In this period, the growth rate of $C$. canephora trees is higher (31), and these nutrients play a fundamental role in plant metabolism and are essential for the functioning of the photosynthetic apparatus. Nitrogen is a constituent of many plant cell components such as chlorophyll, amino acids and nucleic acids, $\mathrm{P}$ is a component of respiration and photosynthesis intermediates, as well as nucleotides used in plant energy metabolism such as ATP, and K plays an important role in regulating the osmotic potential of plant cells, with direct participation in stomatal opening (42). 
Distinct letters in a column differ from each other by the F test at $5 \%$ probability.

Las letras distintas en una columna difieren entre sí por la prueba

F con una probabilidad del $5 \%$.
Conversely to the primary macronutrients ( $\mathrm{N}, \mathrm{P}$ and $\mathrm{K}$ ) the leaf concentrations of $\mathrm{Mg}$, $\mathrm{Fe}, \mathrm{Mn}$ and $\mathrm{B}$ were higher during pre-flowering, namely 44.88\%, 29.95\%, 54.01\%. and $15.22 \%$ higher, respectively, than during grain filling (table 4). Higher concentrations of these nutrients during pre-flowering were also reported by Partelli et al. (2016; 2018). All of these nutrients are important for plant development and their concentrations should be maintained at appropriate levels in plant tissues, according to the metabolic demand. Magnesium is a constituent of the chlorophyll molecule and required by a series of enzymes involved in phosphate transfer, Fe plays an important role as a component of enzymes involved in electron transfer, B is involved in cell elongation and nucleic acid metabolism., and $\mathrm{Mn}$ is required for some enzyme activities, such as decarboxylases and dehydrogenases involved in the Krebs cycle (42).

Table 4. Mean leaf concentrations of N, P, K, Mg, Fe, Mn and B in 42 Coffea canephora genotypes during pre-flowering and grain filling. Nova Venécia, ES - Brazil.

Tabla 4. Concentraciones medias de hojas de N, P, K, Mg, Fe, Mn y B en 42 genotipos de Coffea canephora durante la floración previa y el llenado de grano. Nova Venécia, ES - Brasil.

\begin{tabular}{|l|c|c|c|c|c|c|c|}
\hline \multirow{2}{*}{ Period } & \multicolumn{3}{|c|}{ - - Macronutrients (g.kg-1) - - } & \multicolumn{3}{c|}{ - Micronutrients (mg.kg-1) - } \\
\cline { 2 - 8 } & $\mathrm{N}$ & $\mathrm{P}$ & $\mathrm{K}$ & $\mathrm{Mg}$ & Fe & Mn & $\mathrm{B}$ \\
\hline Pre-flowering & $24.93 \mathrm{~b}$ & $0.99 \mathrm{~b}$ & $9.32 \mathrm{~b}$ & $6.94 \mathrm{a}$ & $102.46 \mathrm{a}$ & $723.26 \mathrm{a}$ & $67.72 \mathrm{a}$ \\
\hline Grain filling & $28.32 \mathrm{a}$ & $1.17 \mathrm{a}$ & $13.95 \mathrm{a}$ & $4.79 \mathrm{~b}$ & $78.84 \mathrm{~b}$ & $469.60 \mathrm{~b}$ & $58.77 \mathrm{~b}$ \\
\hline
\end{tabular}

Based on the mean grouping by the Scott-Knott test, the genotypes were divided into two dissimilar groups for leaf concentrations of N, P, K, Fe and Mn. For Mg and B concentrations of the genotypes, the variability was highest and three and four dissimilar groups, respectively, were formed (table 5, page 28). The same genotypes identified in the group with highest means for a given nutrient also appear in the group with the lowest means for another nutrient. However, genotype 3 stood out for appearing more frequently in the group with highest means and was grouped in the cluster of highest means for six nutrients $(\mathrm{N}, \mathrm{K}, \mathrm{Mg}, \mathrm{Fe}, \mathrm{Mn}, \mathrm{B})$. On the other hand, genotypes 5, 8, 14, 17 and 30 were not found in the group with highest means for leaf concentrations of any evaluated nutrient.

Significant differences between leaf nutrient concentrations of $C$. canephora genotypes were also reported by Gomes et al. (2016) and Martins et al. (2019b). These differences between genotypes may be related to nutrient uptake affinity, compartmentalization in roots or other plant organs, mobility in xylem and phloem vessels and changes in the rhizosphere during growth (25). Another important factor is that the biomass accumulation rates of $C$. canephora genotypes differ from each other (32), i.e., nutrient dilution effects may occur in genotypes with higher and effects of nutrient concentration in genotypes with lower biomass accumulation rates. These genetic variations cause the differences in leaf nutrient contents, indicating a higher or lower efficiency of nutrient uptake, translocation or use by the plant between cultivars or lines (12), and consequently, the possibility of improving and/or selecting more efficient cultivars for nutrient use (13).

The significance of interactions for $\mathrm{Ca}, \mathrm{S}$ and $\mathrm{Cu}$ concentrations indicated a differential response of genotypes to the two sampling periods. For pre-flowering, the genotypes were clustered into three groups for leaf concentrations of $\mathrm{Ca}, \mathrm{S}$ and $\mathrm{Cu}$. For grain filling, two groups were formed for $\mathrm{Ca}$ and $\mathrm{Cu}$ and four for $\mathrm{S}$ (table 6, page 29).

For nutrient $\mathrm{Ca}$, the leaf concentration of none of the evaluated genotypes was higher during grain filling than pre-flowering, but was mostly statistically equal in both periods or lower during grain filling, indicating a tendency to higher Ca concentrations during pre-flowering (table 6, page 29). Higher Ca concentrations during pre-flowering were also reported by Partelli et al. (2016; 2018). Genotypes 1, 6, 10, 11 and 16 stood out for leaf Ca concentration for being clustered in the group with the highest means for both periods. This nutrient fulfills two distinct functions in plants - a structural and a signaling, i.e., it serves as a secondary messenger that triggers plant responses to environmental stimuli (9). 
Table 5. Mean leaf concentration of N, P, K, Mg, Fe, Mn and B in 42 Coffea canephora genotypes. Nova Venécia, ES - Brazil.

Tabla 5. Concentración media de hojas de N, P, K, Mg, Fe, Mn y B en 42 genotipos de Coffea canephora. Nova Venécia, ES - Brasil.

Means followed by the same letter in a column do not differ from each other by the Scott-Knott test at $5 \%$ probability.

Las medias seguidas de la misma letra en una columna no difieren entre sí en la prueba de Scott-Knott con una probabilidad del 5\%.

\begin{tabular}{|c|c|c|c|c|c|c|c|}
\hline \multirow{2}{*}{ Genotype } & \multicolumn{4}{|c|}{ ——— Macronutrients $\left(\mathrm{g} \cdot \mathrm{kg}^{-1}\right)-—-—$} & \multicolumn{3}{|c|}{ — Micronutrients (mg.kg-1) - } \\
\hline & $\mathrm{N}$ & $\mathrm{P}$ & $\mathrm{K}$ & Mg & $\mathrm{Fe}$ & $\mathrm{Mn}$ & B \\
\hline 1 & $28.23 \mathrm{a}$ & $1.06 \mathrm{~b}$ & $10.52 \mathrm{~b}$ & $6.29 \mathrm{~b}$ & $86.33 \mathrm{~b}$ & $675.16 \mathrm{a}$ & $82.16 \mathrm{a}$ \\
\hline 2 & $28.71 \mathrm{a}$ & $1.05 \mathrm{~b}$ & $11.87 \mathrm{a}$ & $5.53 \mathrm{c}$ & $84.33 \mathrm{~b}$ & $832.33 \mathrm{a}$ & $70.33 \mathrm{~b}$ \\
\hline 3 & $28.71 \mathrm{a}$ & $1.05 \mathrm{~b}$ & $12.29 \mathrm{a}$ & $7.26 \mathrm{a}$ & $111.16 \mathrm{a}$ & $647.50 \mathrm{a}$ & $88.83 a$ \\
\hline 4 & $25.28 \mathrm{~b}$ & $1.08 \mathrm{~b}$ & $12.39 \mathrm{a}$ & $5.25 \mathrm{c}$ & $84.50 \mathrm{~b}$ & $519.83 \mathrm{~b}$ & $50.50 \mathrm{~d}$ \\
\hline 5 & $25.41 \mathrm{~b}$ & $1.03 \mathrm{~b}$ & $11.35 \mathrm{~b}$ & $5.77 \mathrm{c}$ & $87.50 \mathrm{~b}$ & $550.16 \mathrm{~b}$ & $61.00 \mathrm{c}$ \\
\hline 6 & $26.13 \mathrm{~b}$ & $0.97 \mathrm{~b}$ & $9.89 \mathrm{~b}$ & $8.53 \mathrm{a}$ & $92.66 \mathrm{~b}$ & $680.50 \mathrm{a}$ & $83.16 \mathrm{a}$ \\
\hline 7 & $27.53 \mathrm{a}$ & $1.15 \mathrm{a}$ & $10.21 \mathrm{~b}$ & $7.55 \mathrm{a}$ & $83.50 \mathrm{~b}$ & $757.83 \mathrm{a}$ & $65.50 \mathrm{c}$ \\
\hline 8 & $26.85 \mathrm{~b}$ & $1.01 \mathrm{~b}$ & $10.21 \mathrm{~b}$ & $6.58 \mathrm{~b}$ & 89.16 b & $553.66 \mathrm{~b}$ & $58.50 \mathrm{c}$ \\
\hline 9 & $26.25 \mathrm{~b}$ & $1.16 \mathrm{a}$ & $11.56 \mathrm{a}$ & $5.82 \mathrm{c}$ & $88.16 \mathrm{~b}$ & $748.50 \mathrm{a}$ & $63.66 \mathrm{c}$ \\
\hline 10 & $26.21 \mathrm{~b}$ & $0.99 \mathrm{~b}$ & $11.56 \mathrm{a}$ & $6.44 \mathrm{~b}$ & $105.83 \mathrm{a}$ & $535.33 \mathrm{~b}$ & $59.33 \mathrm{c}$ \\
\hline 11 & $25.18 \mathrm{~b}$ & $1.02 \mathrm{~b}$ & $11.77 \mathrm{a}$ & $6.00 \mathrm{~b}$ & $101.16 \mathrm{a}$ & $628.83 \mathrm{a}$ & $70.16 \mathrm{~b}$ \\
\hline 12 & $26.42 \mathrm{~b}$ & $1.14 \mathrm{a}$ & $12.81 \mathrm{a}$ & $5.63 \mathrm{c}$ & $88.16 \mathrm{~b}$ & $719.16 \mathrm{a}$ & $53.83 \mathrm{~d}$ \\
\hline 13 & $28.66 \mathrm{a}$ & $1.11 \mathrm{a}$ & $12.08 \mathrm{a}$ & $6.33 \mathrm{~b}$ & $85.00 \mathrm{~b}$ & $572.66 \mathrm{~b}$ & $65.00 \mathrm{c}$ \\
\hline 14 & $24.94 \mathrm{~b}$ & $1.05 \mathrm{~b}$ & $10.00 \mathrm{~b}$ & $6.82 \mathrm{~b}$ & $85.00 \mathrm{~b}$ & $530.00 \mathrm{~b}$ & $61.66 \mathrm{c}$ \\
\hline 15 & $26.32 \mathrm{~b}$ & $1.03 \mathrm{~b}$ & $11.56 \mathrm{a}$ & $6.41 \mathrm{~b}$ & 87.16 b & $630.33 \mathrm{a}$ & $66.50 \mathrm{c}$ \\
\hline 16 & $26.62 \mathrm{~b}$ & $1.05 \mathrm{~b}$ & $10.94 \mathrm{~b}$ & $7.72 \mathrm{a}$ & $97.50 \mathrm{a}$ & $675.66 \mathrm{a}$ & $78.16 \mathrm{a}$ \\
\hline 17 & $25.66 \mathrm{~b}$ & $1.04 \mathrm{~b}$ & $10.73 \mathrm{~b}$ & $5.64 \mathrm{c}$ & $84.83 \mathrm{~b}$ & $485.50 \mathrm{~b}$ & $54.00 \mathrm{~d}$ \\
\hline 18 & $26.42 \mathrm{~b}$ & $1.09 \mathrm{a}$ & $12.08 \mathrm{a}$ & $6.11 \mathrm{~b}$ & $88.83 \mathrm{~b}$ & $767.16 \mathrm{a}$ & $64.50 \mathrm{c}$ \\
\hline 19 & $26.20 \mathrm{~b}$ & $1.03 \mathrm{~b}$ & $13.02 \mathrm{a}$ & $5.13 \mathrm{c}$ & $103.66 \mathrm{a}$ & $478.33 \mathrm{~b}$ & $54.33 \mathrm{~d}$ \\
\hline 20 & $26.33 \mathrm{~b}$ & $1.03 \mathrm{~b}$ & $12.29 \mathrm{a}$ & $4.34 \mathrm{c}$ & $78.83 \mathrm{~b}$ & $542.66 \mathrm{~b}$ & $50.50 \mathrm{~d}$ \\
\hline 21 & $26.55 \mathrm{~b}$ & $1.17 \mathrm{a}$ & $12.40 \mathrm{a}$ & $6.06 \mathrm{~b}$ & $76.50 \mathrm{~b}$ & $411.33 \mathrm{~b}$ & $63.16 \mathrm{c}$ \\
\hline 22 & $26.76 \mathrm{~b}$ & $1.02 \mathrm{~b}$ & $12.60 \mathrm{a}$ & $7.31 \mathrm{a}$ & $89.16 \mathrm{~b}$ & $585.50 \mathrm{~b}$ & $63.00 \mathrm{c}$ \\
\hline 23 & $26.84 \mathrm{~b}$ & $1.12 \mathrm{a}$ & $13.33 \mathrm{a}$ & $5.34 \mathrm{c}$ & $88.50 \mathrm{~b}$ & $711.33 \mathrm{a}$ & $71.33 \mathrm{~b}$ \\
\hline 24 & $26.47 \mathrm{~b}$ & $1.17 \mathrm{a}$ & $11.25 \mathrm{~b}$ & $5.45 \mathrm{c}$ & $88.00 \mathrm{~b}$ & $491.83 \mathrm{~b}$ & $63.83 c$ \\
\hline 25 & $28.21 \mathrm{a}$ & $1.16 \mathrm{a}$ & $11.56 \mathrm{a}$ & $5.39 \mathrm{c}$ & $122.16 \mathrm{a}$ & $333.66 \mathrm{~b}$ & $52.83 \mathrm{~d}$ \\
\hline 26 & $27.77 \mathrm{a}$ & $1.12 \mathrm{a}$ & $14.48 \mathrm{a}$ & $4.69 \mathrm{c}$ & 89.66 b & $471.00 \mathrm{~b}$ & $60.33 c$ \\
\hline 27 & $27.09 \mathrm{a}$ & $1.12 \mathrm{a}$ & $11.77 \mathrm{a}$ & $5.41 \mathrm{c}$ & $85.83 \mathrm{~b}$ & $718.00 \mathrm{a}$ & $67.50 \mathrm{~b}$ \\
\hline 28 & $27.61 \mathrm{a}$ & $1.08 \mathrm{~b}$ & $14.06 \mathrm{a}$ & $4.47 \mathrm{c}$ & $85.16 \mathrm{~b}$ & $536.66 \mathrm{~b}$ & $53.16 \mathrm{~d}$ \\
\hline 29 & $25.88 \mathrm{~b}$ & $1.11 \mathrm{a}$ & $11.88 \mathrm{a}$ & $4.69 \mathrm{c}$ & $109.33 \mathrm{a}$ & $571.50 \mathrm{~b}$ & $53.00 \mathrm{~d}$ \\
\hline 30 & $25.88 \mathrm{~b}$ & $0.99 \mathrm{~b}$ & $10.00 \mathrm{~b}$ & $5.25 \mathrm{c}$ & $86.33 \mathrm{~b}$ & $545.83 \mathrm{~b}$ & $68.50 \mathrm{~b}$ \\
\hline 31 & $27.63 \mathrm{a}$ & $1.21 \mathrm{a}$ & $10.83 \mathrm{~b}$ & $4.69 \mathrm{c}$ & $112.16 \mathrm{a}$ & $353.83 \mathrm{~b}$ & $65.66 \mathrm{c}$ \\
\hline 32 & $26.16 \mathrm{~b}$ & $0.97 \mathrm{~b}$ & $11.15 \mathrm{~b}$ & $5.24 \mathrm{c}$ & $94.83 \mathrm{~b}$ & $609.16 \mathrm{a}$ & $59.00 \mathrm{c}$ \\
\hline 33 & $27.83 \mathrm{a}$ & $1.12 \mathrm{a}$ & $12.29 \mathrm{a}$ & $5.38 \mathrm{c}$ & $92.16 \mathrm{~b}$ & $611.33 \mathrm{a}$ & $58.50 \mathrm{c}$ \\
\hline 34 & $26.37 \mathrm{~b}$ & $1.15 \mathrm{a}$ & $12.19 \mathrm{a}$ & $5.13 \mathrm{c}$ & $78.50 \mathrm{~b}$ & $623.66 \mathrm{a}$ & $50.16 \mathrm{~d}$ \\
\hline 35 & $26.51 \mathrm{~b}$ & $1.05 \mathrm{~b}$ & $12.81 \mathrm{a}$ & $4.48 \mathrm{c}$ & 88.16 b & $540.16 \mathrm{~b}$ & $55.66 \mathrm{~d}$ \\
\hline 36 & $27.46 \mathrm{a}$ & $1.16 \mathrm{a}$ & $10.52 \mathrm{~b}$ & $6.84 \mathrm{~b}$ & $94.00 \mathrm{~b}$ & $829.33 \mathrm{a}$ & $64.16 \mathrm{c}$ \\
\hline 37 & $26.86 \mathrm{~b}$ & $1.11 \mathrm{a}$ & $11.35 \mathrm{~b}$ & $6.17 \mathrm{~b}$ & $96.16 \mathrm{~b}$ & $626.00 \mathrm{a}$ & $65.83 c$ \\
\hline 38 & $26.56 \mathrm{~b}$ & $1.01 \mathrm{~b}$ & $10.42 \mathrm{~b}$ & $7.11 \mathrm{a}$ & $86.33 \mathrm{~b}$ & $688.00 \mathrm{a}$ & $69.00 \mathrm{~b}$ \\
\hline 39 & $25.34 \mathrm{~b}$ & $1.05 \mathrm{~b}$ & $11.04 \mathrm{~b}$ & $6.27 \mathrm{~b}$ & $74.00 \mathrm{~b}$ & $611.16 \mathrm{a}$ & $73.16 \mathrm{~b}$ \\
\hline 40 & $27.40 \mathrm{a}$ & $1.18 \mathrm{a}$ & $11.87 \mathrm{a}$ & $5.46 \mathrm{c}$ & $76.83 \mathrm{~b}$ & $574.00 \mathrm{~b}$ & $63.50 \mathrm{c}$ \\
\hline 41 & $26.64 \mathrm{~b}$ & $1.06 \mathrm{~b}$ & $12.19 \mathrm{a}$ & $4.33 \mathrm{c}$ & $81.33 \mathrm{~b}$ & $589.33 \mathrm{~b}$ & $52.33 \mathrm{~d}$ \\
\hline 42 & $24.82 \mathrm{~b}$ & $1.03 \mathrm{~b}$ & $9.58 \mathrm{~b}$ & $5.98 \mathrm{~b}$ & $99.16 \mathrm{a}$ & $486.50 \mathrm{~b}$ & $61.16 \mathrm{c}$ \\
\hline
\end{tabular}


Table 6. Partitioning of interaction for $\mathrm{Ca}, \mathrm{S}$ and $\mathrm{Cu}$ leaf concentrations in 42 Coffea canephora genotypes during pre-flowering and grain filling. Nova Venécia, ES - Brazil.

Tabla 6. Particionamiento de la interacción para las concentraciones de hojas de Ca, S y $\mathrm{Cu}$ en 42 genotipos de Coffea canephora durante la floración previa y el llenado de granos. Nova Venécia, ES - Brasil.

Means followed by equal letters, lowercase letters and uppercase letters do not differ from each other by the F and ScottKnott tests, respectively, at $5 \%$ probability. Las medias seguidas de letras iguales, letras minúsculas y letras mayúsculas no difieren entre sí por las pruebas F y Scott-Knott, respectivamente, con un $5 \%$ de probabilidad.

\begin{tabular}{|c|c|c|c|c|c|c|}
\hline \multirow{2}{*}{ Genotypes } & \multicolumn{2}{|c|}{ - - Ca (g.kg-1) - } & \multicolumn{2}{|c|}{- - S (g.kg-1) - - } & \multicolumn{2}{|c|}{ - - Cu (mg.kg-1) -— } \\
\hline & Pre-flowering & Grain filling & Pre-flowering & Grain filling & Pre-flowering & Grain filling \\
\hline 1 & $26.31 \mathrm{Aa}$ & $18.40 \mathrm{Ab}$ & $1.82 \mathrm{Ca}$ & $1.65 \mathrm{Da}$ & $12.66 \mathrm{Ca}$ & $14.66 \mathrm{Ba}$ \\
\hline 2 & $17.39 \mathrm{Ca}$ & $17.30 \mathrm{Aa}$ & $1.82 \mathrm{Ca}$ & $2.10 \mathrm{Ca}$ & $9.33 \mathrm{Cb}$ & $14.00 \mathrm{Ba}$ \\
\hline 3 & $22.06 \mathrm{Ba}$ & $18.90 \mathrm{Aa}$ & $1.71 \mathrm{Ca}$ & $2.17 \mathrm{Ca}$ & $10.33 \mathrm{Cb}$ & $15.33 \mathrm{Ba}$ \\
\hline 4 & $17.84 \mathrm{Ca}$ & 13.37 Ba & $1.98 \mathrm{Ca}$ & $2.29 \mathrm{Ca}$ & $16.00 \mathrm{Ba}$ & $16.66 \mathrm{Ba}$ \\
\hline 5 & $17.57 \mathrm{Ca}$ & $14.78 \mathrm{Ba}$ & $1.55 \mathrm{Ca}$ & $1.96 \mathrm{Ca}$ & $15.66 \mathrm{Ba}$ & $16.00 \mathrm{Ba}$ \\
\hline 6 & $27.29 \mathrm{Aa}$ & $18.24 \mathrm{Ab}$ & $1.89 \mathrm{Cb}$ & $2.56 \mathrm{Ba}$ & $15.66 \mathrm{Ba}$ & $16.66 \mathrm{Ba}$ \\
\hline 7 & $18.01 \mathrm{Ca}$ & $18.95 \mathrm{Aa}$ & $1.78 \mathrm{Ca}$ & $2.20 \mathrm{Ca}$ & $15.00 \mathrm{Ca}$ & $19.00 \mathrm{Aa}$ \\
\hline 8 & $17.65 \mathrm{Ca}$ & $20.21 \mathrm{Aa}$ & $1.52 \mathrm{Cb}$ & $2.06 \mathrm{Ca}$ & $9.00 \mathrm{Cb}$ & $17.00 \mathrm{Ba}$ \\
\hline 9 & $22.11 \mathrm{Ba}$ & 20.84 Aa & $2.13 \mathrm{Bb}$ & $2.88 \mathrm{Ba}$ & $16.66 \mathrm{Ba}$ & $16.66 \mathrm{Ba}$ \\
\hline 10 & $24.74 \mathrm{Aa}$ & $19.28 \mathrm{Ab}$ & $1.75 \mathrm{Cb}$ & $2.56 \mathrm{Ba}$ & $15.00 \mathrm{Cb}$ & $25.00 \mathrm{Aa}$ \\
\hline 11 & $24.80 \mathrm{Aa}$ & $21.35 \mathrm{Aa}$ & $1.88 \mathrm{Ca}$ & $2.20 \mathrm{Ca}$ & $12.00 \mathrm{Ca}$ & $15.00 \mathrm{Ba}$ \\
\hline 12 & $22.39 \mathrm{Ba}$ & $14.95 \mathrm{Bb}$ & $1.62 \mathrm{Ca}$ & $2.02 \mathrm{Ca}$ & $17.00 \mathrm{Ba}$ & $18.00 \mathrm{Aa}$ \\
\hline 13 & $21.26 \mathrm{Ba}$ & $15.93 \mathrm{Bb}$ & $1.88 \mathrm{Ca}$ & $2.20 \mathrm{Ca}$ & 19.33 Аа & $20.66 \mathrm{Aa}$ \\
\hline 14 & $20.72 \mathrm{Ba}$ & $14.00 \mathrm{Bb}$ & $1.86 \mathrm{Ca}$ & $1.59 \mathrm{Da}$ & $14.00 \mathrm{Cb}$ & $20.00 \mathrm{Aa}$ \\
\hline 15 & $22.08 \mathrm{Ba}$ & $18.05 \mathrm{Aa}$ & $1.78 \mathrm{Cb}$ & $2.56 \mathrm{Ba}$ & $16.33 \mathrm{Ba}$ & $18.00 \mathrm{Aa}$ \\
\hline 16 & $25.21 \mathrm{Aa}$ & $19.63 \mathrm{Ab}$ & $2.17 \mathrm{Ba}$ & $2.35 \mathrm{Ca}$ & $15.66 \mathrm{Ba}$ & $15.00 \mathrm{Ba}$ \\
\hline 17 & $22.65 \mathrm{Ba}$ & $16.72 \mathrm{Bb}$ & $1.92 \mathrm{Ca}$ & $2.05 \mathrm{Ca}$ & $15.33 \mathrm{Ba}$ & $16.00 \mathrm{Ba}$ \\
\hline 18 & $17.51 \mathrm{Ca}$ & 17.32 Aa & $1.75 \mathrm{Ca}$ & $1.92 \mathrm{Da}$ & $14.33 \mathrm{Cb}$ & $19.00 \mathrm{Aa}$ \\
\hline 19 & $19.41 \mathrm{Ca}$ & 16.99 Aa & $1.63 \mathrm{Ca}$ & $2.00 \mathrm{Ca}$ & $17.00 \mathrm{Ba}$ & $16.33 \mathrm{Ba}$ \\
\hline 20 & $18.80 \mathrm{Ca}$ & $13.93 \mathrm{Bb}$ & $1.62 \mathrm{Ca}$ & 1.57 Da & $13.00 \mathrm{Ca}$ & $13.00 \mathrm{Ba}$ \\
\hline 21 & $19.83 \mathrm{Ca}$ & $15.58 \mathrm{Ba}$ & $1.71 \mathrm{Ca}$ & $2.03 \mathrm{Ca}$ & $21.00 \mathrm{Aa}$ & $15.33 \mathrm{Bb}$ \\
\hline 22 & $16.92 \mathrm{Ca}$ & $18.67 \mathrm{Aa}$ & $2.09 \mathrm{Bb}$ & $3.52 \mathrm{Aa}$ & $19.00 \mathrm{Aa}$ & $16.33 \mathrm{Ba}$ \\
\hline 23 & $16.41 \mathrm{Ca}$ & $14.72 \mathrm{Ba}$ & $1.86 \mathrm{Ca}$ & $2.12 \mathrm{Ca}$ & $20.33 \mathrm{Aa}$ & 18.66 Aa \\
\hline 24 & $20.80 \mathrm{Ba}$ & $13.33 \mathrm{Bb}$ & $1.55 \mathrm{Ca}$ & $1.68 \mathrm{Da}$ & $15.66 \mathrm{Ba}$ & $16.33 \mathrm{Ba}$ \\
\hline 25 & $16.04 \mathrm{Ca}$ & $12.22 \mathrm{Ba}$ & $1.59 \mathrm{Ca}$ & $1.74 \mathrm{Da}$ & $11.66 \mathrm{Cb}$ & $18.33 \mathrm{Aa}$ \\
\hline 26 & $18.37 \mathrm{Ca}$ & $20.57 \mathrm{Aa}$ & $2.45 \mathrm{Bb}$ & $3.06 \mathrm{Ba}$ & $14.00 \mathrm{Ca}$ & $15.00 \mathrm{Ba}$ \\
\hline 27 & $21.93 \mathrm{Ba}$ & $12.06 \mathrm{Bb}$ & $1.62 \mathrm{Cb}$ & $2.10 \mathrm{Ca}$ & 16.66 Ba & $16.66 \mathrm{Ba}$ \\
\hline 28 & $15.57 \mathrm{Ca}$ & $15.05 \mathrm{Ba}$ & $1.72 \mathrm{Cb}$ & $2.23 \mathrm{Ca}$ & 18.33 Аа & $15.66 \mathrm{Ba}$ \\
\hline 29 & $17.91 \mathrm{Ca}$ & $12.29 \mathrm{Bb}$ & $1.76 \mathrm{Cb}$ & $2.30 \mathrm{Ca}$ & $13.00 \mathrm{Ca}$ & $13.33 \mathrm{Ba}$ \\
\hline 30 & $28.06 \mathrm{Aa}$ & $15.99 \mathrm{Bb}$ & $1.65 \mathrm{Ca}$ & $2.09 \mathrm{Ca}$ & $10.00 \mathrm{Ca}$ & $13.33 \mathrm{Ba}$ \\
\hline 31 & $20.03 \mathrm{Ca}$ & $15.74 \mathrm{Ba}$ & $1.85 \mathrm{Ca}$ & $1.74 \mathrm{Da}$ & $13.33 \mathrm{Ca}$ & $15.33 \mathrm{Ba}$ \\
\hline 32 & $18.86 \mathrm{Ca}$ & $14.32 \mathrm{Ba}$ & $1.89 \mathrm{Ca}$ & $1.85 \mathrm{Da}$ & $13.33 \mathrm{Ca}$ & $15.00 \mathrm{Ba}$ \\
\hline 33 & $17.91 \mathrm{Ca}$ & $18.90 \mathrm{Aa}$ & $2.19 \mathrm{Bb}$ & $2.67 \mathrm{Ba}$ & 17.33 Ba & $21.33 \mathrm{Aa}$ \\
\hline 34 & $16.06 \mathrm{Ca}$ & $14.68 \mathrm{Ba}$ & $1.72 \mathrm{Ca}$ & $2.16 \mathrm{Ca}$ & $20.33 \mathrm{Aa}$ & $18.33 \mathrm{Aa}$ \\
\hline 35 & $19.67 \mathrm{Ca}$ & $14.62 \mathrm{Bb}$ & $1.72 \mathrm{Cb}$ & $2.23 \mathrm{Ca}$ & $17.66 \mathrm{Ba}$ & $15.33 \mathrm{Ba}$ \\
\hline 36 & $22.30 \mathrm{Ba}$ & $15.53 \mathrm{Bb}$ & $1.69 \mathrm{Ca}$ & $2.09 \mathrm{Ca}$ & $19.33 \mathrm{Aa}$ & $21.33 \mathrm{Aa}$ \\
\hline 37 & $21.51 \mathrm{Ba}$ & $15.37 \mathrm{Bb}$ & $3.03 \mathrm{Ab}$ & $3.81 \mathrm{Aa}$ & $21.33 \mathrm{Aa}$ & $16.66 \mathrm{Bb}$ \\
\hline 38 & $21.00 \mathrm{Ba}$ & $16.16 \mathrm{Bb}$ & $2.02 \mathrm{Cb}$ & $2.56 \mathrm{Ba}$ & $19.33 \mathrm{Aa}$ & 17.66 Аa \\
\hline 39 & $22.57 \mathrm{Ba}$ & $15.98 \mathrm{Bb}$ & $2.03 \mathrm{Ca}$ & $2.23 \mathrm{Ca}$ & $14.00 \mathrm{Ca}$ & $12.00 \mathrm{Ba}$ \\
\hline 40 & $21.45 \mathrm{Ba}$ & $16.07 \mathrm{Bb}$ & $1.90 \mathrm{Ca}$ & $2.36 \mathrm{Ca}$ & $22.66 \mathrm{Aa}$ & $18.00 \mathrm{Ab}$ \\
\hline 41 & $16.09 \mathrm{Ca}$ & $13.33 \mathrm{Ba}$ & $1.82 \mathrm{Cb}$ & $2.39 \mathrm{Ca}$ & $18.66 \mathrm{Aa}$ & $16.66 \mathrm{Ba}$ \\
\hline 42 & $21.65 \mathrm{Ba}$ & $13.52 \mathrm{Bb}$ & $1.58 \mathrm{Cb}$ & $2.79 \mathrm{Ba}$ & $11.00 \mathrm{Cb}$ & $16.00 \mathrm{Ba}$ \\
\hline Mean & 20.40 & 16.28 & 1.84 & 2.25 & 15.65 & 16.78 \\
\hline
\end{tabular}


For leaf S concentration, the genotypes responded inversely to that of $\mathrm{Ca}$, since the S concentrations of 16 genotypes were highest during grain filling, while those of the others were considered statistically the same in both periods, indicating a tendency to higher S concentrations during grain filling (table 6, page 29). Genotype 37 stood out for forming a separate group of high $\mathrm{S}$ concentration during pre-flowering, superior to the other groups. For the grain filling period, genotype 37 and 22 formed a group with the highest means. The S content in plant tissues of these lines is extremely important, as this nutrient is a constituent of coenzymes, vitamins and certain amino acids that are essential for the metabolism, while a deficiency, similarly as in the case of nitrogen, can lead to plant growth reduction (5).

Similar to $\mathrm{S}$, a trend of higher $\mathrm{Cu}$ concentration during grain filling can be observed, except for genotypes 21,37 and 40 , for which the mean concentrations were higher during pre-flowering (table 6, page 29). The importance of adequate $\mathrm{Cu}$ concentrations in plants is related to the functions of the element, which is essential for mitochondrial respiration, carbon and nitrogen metabolism, for protection of oxidative stress and necessary for cell wall synthesis (3). It also participates in photosynthetic reactions. since more than half of the $\mathrm{Cu}$ in plants is found in chloroplasts (21). The genotypes 13, 23, 34, 36, 38 and 40 were found to have the highest leaf $\mathrm{Cu}$ concentrations in both evaluated periods.

The grouping of genotypes by the UPGMA hierarchical clustering, using Mahalanobis' generalized distance $\left(D^{2}\right)$ as a measure of genetic dissimilarity for the macro- and micronutrient leaf concentrations in the periods pre-flowering and grain filling, allowed the formation of a dendrogram. By establishing a maximum limit of $60 \%$ dissimilarity between genotypes, the formation of four groups was observed (figure 1).

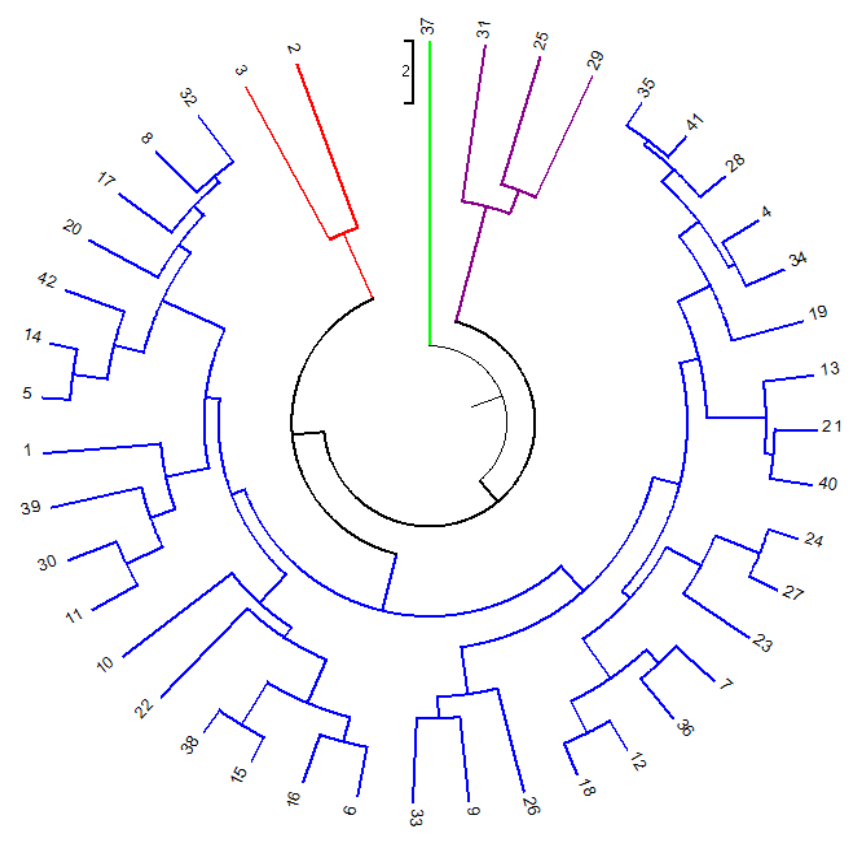

Figure 1. Representative dendrogram of genetic dissimilarity among 42 C. canephora genotypes, obtained by UPGMA clustering, using Mahalanobis' generalized distance $\left(\mathrm{D}^{2}\right)$ for leaf concentrations of nitrogen, phosphorus, potassium, calcium, magnesium, sulfur, iron, copper, manganese and boron during pre-flowering and grain filling. Cophenetic correlation $=0.62$.

Figura 1. Dendrograma representativo de la diferencia genética entre 42 genotipos de $C$. canephora, obtenidos por agrupamiento UPGMA, utilizando la distancia generalizada de Mahalanobis $\left(\mathrm{D}^{2}\right)$ para las concentraciones foliares de nitrógeno, fósforo, potasio, calcio, magnesio, azufre, hierro, cobre, manganeso y boro durante pre-floración y relleno de grano. Correlación cophenetic $=0,62$. 
The first group established by the UPGMA method consisted of only genotype 37 . The second group comprised three genotypes, 31, 25 and 29. Genotypes 2 and 3 formed the third group, and the fourth group contained 36. genotypes, representing $85.71 \%$ of all evaluated genotypes. The formation of the groups, considered divergent, indicates the variability between $C$. canephora genotypes for leaf nutrient concentrations. By the hierarchical UPGMA clustering, Gomes et al. (2016) and Martins et al. (2019b) also observed the formation of divergent groups of $C$. canephora genotypes for nutritional characteristics. In breeding programs, the study of genetic diversity by multivariate techniques is useful for planning and to define work strategies (22).

According to the grouping by the UPGMA method, the mean of the evaluated characteristics was calculated for each group, thus allowing a comparison of the leaf concentrations that differentiate the groups (table 7). In the first group, with only genotype 37, the highest $\mathrm{S}$ and $\mathrm{Cu}$ and lowest $\mathrm{K}$ concentrations were found. The second group had the highest $\mathrm{P}$ and Fe and lowest Mg, Mn, B., Ca and S leaf concentrations. For the third group, highest N, K, Mg, $\mathrm{Mn}, \mathrm{B}$ and $\mathrm{Ca}$ concentrations and lowest $\mathrm{P}$ and $\mathrm{Cu}$ concentrations were recorded. The fourth group differs from the others by not presenting highest leaf concentrations of any of the evaluated nutrients, but the lowest $\mathrm{N}$ and Fe concentrations.

Table 7. Means of macro- and micronutrient leaf concentrations in Coffea canephora for groups formed by UPGMA clustering based on Mahalanobis' generalized distance $\left(\mathrm{D}^{2}\right)$. Nova Venécia, ES - Brazil.

Tabla 7. Medias de las concentraciones de hojas de macro y micronutrientes en Coffea canephora para grupos formados por agrupamiento UPGMA basado en la distancia generalizada de Mahalanobis $\left(\mathrm{D}^{2}\right)$. Nova Venécia, ES - Brasil.

\begin{tabular}{|c|c|c|c|c|c|c|c|c|c|c|}
\hline \multirow{3}{*}{ Group } & \multicolumn{6}{|c|}{ Macronutrients } & \multicolumn{4}{|c|}{ Micronutrients } \\
\hline & \multicolumn{6}{|c|}{ 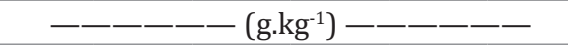 } & \multicolumn{4}{|c|}{-——- $\left(\mathrm{mg} \cdot \mathrm{kg}^{-1}\right)-—-—$} \\
\hline & $\mathrm{N}$ & $\mathrm{P}$ & $\mathrm{K}$ & $\mathrm{Ca}$ & $\mathrm{Mg}$ & S & $\mathrm{Fe}$ & $\mathrm{Cu}$ & Mn & B \\
\hline G1 & 26.86 & 1.11 & 11.35 & 18.44 & 6.17 & 3.42 & 96.16 & 19.00 & 626.00 & 65.83 \\
\hline G2 & 27.24 & 1.16 & 11.42 & 15.71 & 4.92 & 1.83 & 114.55 & 14.16 & 419.66 & 57.16 \\
\hline G3 & 28.71 & 1.05 & 12.08 & 18.91 & 6.40 & 1.95 & 97.75 & 12.25 & 739.92 & 79.58 \\
\hline G4 & 26.52 & 1.07 & 11.64 & 18.53 & 5.90 & 2.04 & 88.12 & 16.53 & 602.37 & 62.77 \\
\hline
\end{tabular}

To determine the relative contribution of leaf concentration of evaluated nutrients, we used the method of Singh (1981), resulting in values from 4.69 to $22.52 \%$ (table 8). Leaf concentrations that contributed most to genetic divergence among the 42 genotypes were nutrients S (22.52\%), Cu (11.54\%), B (11.46\%) and Mg (11.10\%), which together accounted for $55.62 \%$ of the variability between the genotypes.

Table 8. Relative contribution of leaf concentration of macro- and micronutrients to genetic diversity in 42 Coffea canephora genotypes, according to Singh's method (1981), Mahalanobis' generalized distance $\left(\mathrm{D}^{2}\right)$. Nova Venécia, ES - Brazil.

Tabla 8. Contribución relativa de la concentración foliar de macro y micronutrientes a la diversidad genética en 42 genotipos de Coffea canephora, según el método de Singh

(1981), distancia generalizada de Mahalanobis ( $\left.{ }^{2}\right)$. Nova Venécia, ES - Brasil.

S. j: value estimated by the statistic of Singh (1981).

S. j: valor estimado por la estadística de Singh (1981).

\begin{tabular}{|c|c|c|c|}
\hline Nutrients & S.j & S.j (\%) & Cumulative S.j (\%) \\
\hline $\mathrm{S}$ & 2539.352978 & 22.52 & 22.52 \\
\hline $\mathrm{Cu}$ & 1300.724814 & 11.54 & 34.06 \\
\hline $\mathrm{B}$ & 1291.781259 & 11.46 & 45.52 \\
\hline $\mathrm{Mg}$ & 1250.1168 & 11.10 & 56.62 \\
\hline $\mathrm{P}$ & 1122.41325 & 9.96 & 66.58 \\
\hline $\mathrm{Ca}$ & 1102.525267 & 9.78 & 76.36 \\
\hline $\mathrm{Fe}$ & 747.869333 & 6.63 & 82.99 \\
\hline $\mathrm{Mn}$ & 730.187555 & 6.48 & 89.47 \\
\hline $\mathrm{K}$ & 660.416076 & 5.86 & 95.33 \\
\hline $\mathrm{N}$ & 528.287387 & 4.69 & 100 \\
\hline
\end{tabular}


Leaf $\mathrm{N}$ concentration was the trait that contributed least to the genetic diversity among genotypes (table 8, page 31). Similarly, Starling et al. (2019) reported that the N concentration in plant tissues of $C$. canephora genotypes had the lowest relative contribution to genetic diversity by the method of Sing (1981). The study of the relative importance of traits for genetic divergence is highly relevant, since it estimates values based on which those of minor importance for genotype discrimination can be eliminated (20).

\section{Conclusions}

Genetic divergence is available among C. canephora genotypes for leaf nutrient concentration during the phenological stages pre-anthesis and grain filling.

Genotype 3 (Bicudo) stands out with the highest leaf concentrations of six evaluated nutrients (N, K, Mg, Fe, Mn and B).

Leaf $S$ concentration contributed most to the genetic diversity among the 42 evaluated genotypes, followed by $\mathrm{Cu}, \mathrm{B}$ and $\mathrm{Mg}$ concentrations.

To improve the efficiency of nutritional diagnosis, it is suggested that apart from the sampling periods of pre-flowering and grain filling, the genotypic variability for leaf nutrient concentration should also be taken into consideration.

\section{REFERENCES}

1. Alvares, C. A.; Stape, J. L.; Sentelhas, P. C.; Gonçalves, J. L. M.; Sparovek, G. 2013. Köppen’s climate classification map for Brazil. Meteorologische Zeitschrift. 22: 711-728. DOI: 10.1127/09412948/2013/0507

2. Amaral, J. F. T.; Martinez, H. E. P.; Laviola, B. G.; Fernandes Filho, E. I.; Cruz, C. D. 2011. Eficiência de utilização de nutrientes por cultivares de cafeeiro. Ciência Rural. 41(4): 621-629. DOI: 10.1590/S0103-84782011005000027

3. Apáez Barrios, P.; Rocha Granados, M. del C.; Pedraza Santos, M. E.; Raya Montaño, Y. A. 2018. Effect of foliar copper application on yield and anthocyanin concentration in Hibiscus sabdariffa calyces. Revista de la Facultad de Ciencias Agrarias. Universidad Nacional de Cuyo. Mendoza. Argentina. 50(2): 65-75.

4. Bragança, S. M.; Carvalho, C. H. S.; Fonseca, A. F. A.; Ferrão, R. G. 2001. Variedades clonais de café Conilon para o estado do Espírito Santo. Pesquisa Agropecuária Brasileira. 36(5): 765770. DOI: $10.1590 / \mathrm{S} 0100-204 X 2001000500006$

5. Capaldi, F. R.; Gratão, P. L.; Reis, A. R.; Lima, L. W.; Azevedo, R. A. 2015. Sulfur metabolism and stress defense responses in plants. Tropical Plant Biology. 8(3-4): 60-73. DOI: 10.1007/s12042015-9152-1

6. CONAB - Companhia Nacional de Abastecimento. Acompanhamento da safra brasileira: quarto levantamento safra café 2018. 2020. https://www.conab.gov.br/component/ k2/item/download/24571_eec1a3f8fdc30883717a497a09f7d159 (Accessed February 2020).

6. Covre, A. M.; Canal, L.; Partelli, F. L.; Alexandre, R. S.; Ferreira, A.; Vieira, H. D. 2016. Development of clonal seedlings of promising Conilon coffee (Coffea canephora) genotypes. Australian Journal of Crop Science. 10(3): 385-392. DOI: 10.21475/ajcs.2016.10.03.p7235

8. Cruz, C. D. 2016. Programa Genes - Ampliado e integrado aos aplicativos R, Matlab e Selegen. Acta Scientiarum. Agronomy. 38(4): 547-552. DOI: 10.4025/actasciagron.v38i4.32629

9. Dodd, A. N.; Kudla, J.; Sanders, D. 2010. The language of calcium signaling. Annual review of Plant Biology. 61: 593-620. DOI: 10.1146/annurev-arplant-070109-104628

10. Fageria, N. K. 1998. Otimização da eficiência nutricional na produção das culturas. Revista Brasileira de Engenharia Agrícola e Ambiental. 2(1): 6-16. DOI: 10.1590/1807-1929/agriambi. v02n01p6-16

11. Ferrão, R. G.; Cruz, C. D.; Ferreira, A.; Cecon, P. R.; Ferrão, M. A. G.; Fonseca, A. F. A.; Carneiro, P. C. S.; Silva, M. F. 2008. Parâmetros genéticos em café Conilon. Pesquisa agropecuária brasileira. 43(1): 61-69. DOI: 10.1590/S0100-204X2008000100009

12. Ferreira, A. D.; Carvalho, A. M.; Mendes, A. N. G.; Carvalho, G. R.; Botelho, C. E.; Carvalho, J. G. 2010. Absorção, translocação e eficiência no uso dos macronutrientes em cafeeiros (Coffea arabica) enxertados em Apoatã IAC 2258 (Coffea canephora). Interciencia. 35(11): 818822.

13. Ferreira, A. D.; Carvalho, G. R.; Abrahão, J. C. R.; Rezende, R. M.; Botelho, C. E.; Carvalho, A. M. 2013. Dinâmica dos micronutrientes em cafeeiros enxertados. Revista Ceres. 60(2): 262-269. DOI: 10.1590/S0034-737X2013000200016 
14. Ferreira, R. T.; Viana, A. P.; Silva, F. H. L.; Santos, E. A.; Santos, J. O. 2016. Seleção recorrente intrapopulacional em maracujazeiro-azedo via modelos mistos. Revista Brasileira de Fruticultura. 38(1): 158-166. DOI: 10.1590/0100-2945-260/14

15. Fonseca, A. F. A.; Sediyama, T.; Cruz, C. D.; Sakaiyama, N. S.; Ferrão, M. A. G.; Ferrão, R. G.; Bragança, S. M. 2006. Divergência genética em café Conilon. Pesquisa Agropecuária Brasileira. 41(4): 599-605. DOI: 10.1590/S0100-204X2006000400008

16. Gabelman, W. H.; Gerloff, G. C. 1983. The search for and interpretation of genetic controls that enhance plant growth under deficiency levels of a macronutrient. Plant and Soil. 72(2): 335-350. DOI: 10.1007/978-94-009-6836-3_45

17. Giles, J. A. D.; Partelli, F. L.; Ferreira, A.; Rodrigues, J. P.; Oliosi, G.; Silva, F. H. L. 2018. Genetic diversity of promising 'conilon' coffee clones based on morpho-agronomic variables. Anais da Academia Brasileira de Ciências. 90(2): 2437-2446. DOI: 10.1590/00013765201820170523

18. Giles, J. A. D.; Ferreira, A. D.; Partelli, F. L.; Aoyama, E. M.; Ramalho, J. C.; Ferreira, A.; Falqueto, A. R. 2019. Divergence and genetic parameters between Coffea sp. genotypes based in foliar morpho-anatomical traits. Scientia Horticulturae. 245: 231-236. DOI: 10.1016/j. scienta.2018.09.038

19. Gomes, W. R.; Rodrigues, W. P.; Vieira, H. D.; Oliveira, M. G.; Dias, J. R. M.; Partelli, F. L. 2016. Genetic diversity of standard leaf nutrients in Coffea canephora genotypes during phenological phases. Genetics and Molecular Research. 15(4): 1-13. DOI: 10.4238/gmr.15048839

20. Guedes, J. M.; Vilela, D. J. M.; Rezende, J. C.; Silva, F. L.; Botelho, C. E.; Carvalho, S. P. 2013. Divergência genética entre cafeeiros do germoplasma Maragogipe. Bragantia. 72(2): 127-132. DOI: 10.1590/S0006-87052013000200003

21. Hänsch, R.; Mendel, R. R. 2009. Physiological functions of mineral micronutrients (Cu, Zn, Mn, Fe, Ni, Mo, B, Cl). Current Opinion in Plant Biology. 12: 259-266. DOI: 10.1016/j.pbi.2009.05.006

22. Ivoglo, M. G.; Fazuoli, L. C.; Oliveira, A. C. B.; Gallo, P. B.; Mistro, J. C.; Silvarolla, M. B.; Toma-Braghini, M. 2008. Divergência genética entre progênies de café robusta. Bragantia. 67(4): 823-831. DOI: 10.1590/S0006-87052008000400003

23. López-Lima, D.; Carrión, G.; Sánchez-Nava, P.; Desgarennes, D.; Villain, L. 2020. Fungal diversity and Fusarium oxysporum pathogenicity associated with coffee corky-root disease in Mexico. Revista de la Facultad de Ciencias Agrarias. Universidad Nacional de Cuyo. Mendoza. Argentina. 52(1): 276-292.

24. Marré, W. B.; Partelli, F. L.; Espindula, M. C.; Dias, J. R. M.; Gontijo, I.; Vieira, H. D. 2015. Micronutrient accumulation in conilon coffee berries with different maturation cycles. Revista Brasileira de Ciência do Solo. 39: 1456-1462. DOI: 10.1590/01000683rbcs20140649

25. Marschner, H. 2012. Marschner's Mineral nutrition of higher plants ( $3^{\text {nd }}$ ed.). London: Academic Press.

26. Martins, L. D.; Tomaz, M. A.; Amaral, J. F. T.; Bragança, S. M.; Martinez, H. E. P. 2013. Efficiency and response of conilon coffee clones to phosphorus fertilization. Revista Ceres. 60(3): 406411. DOI: 10.1590/S0034-737X2013000300014

27. Martins, L. D.; Rodrigues, W. N.; Machado, L. S.; Brinate, S. V. B.; Colodetti, T. V.; Ferreira, D. S.; Cogo, A. D.; Apostolico, M. A.; Teodoro, P. E.; Tomaz, M. A.; Amaral, J. F. T.; Partelli, F. L.; Ramalho, J. C. 2016. Genotypes of conilon coffee can be simultaneously clustered for efficiencies of absorption and utilization of N, P and K. African Journal of Agricultural Research. 11(38): 3633-3642. DOI: $10.5897 /$ AJAR2016.11418

28. Martins, Q. M.; Partelli, F. L.; Golynski, A.; Pimentel, N. S.; Ferreira, A.; Bernardes, C. O.; Ribeiro Barros, A. I.; Ramalho, J. C. 2019a. Adaptability and stability of Coffea canephora genotypes cultivated at high altitude and subjected to low temperature during the winter. Scientia Horticulturae. 252: 238-242. DOI: 10.1016/j.scienta.2019.03.044

29. Martins, M. Q.; Partelli, F. L.; Ferreira, A.; Bernardes, C. O.; Golynski, A.; Vieira, H. D.; Freitas, M. S. M.; Ramalho, J. C. 2019b. Genetic variability on nutrient contents in Coffea canephora genotypes cultivated at 850 meters of altitude in two crop seasons. Functional Plant Breeding Journal. 1(1): 1-12. DOI: 10.35418/2526-4117/v1n1a6

30. Partelli, F. L.; Vieira, H. D.; Carvalho, V. B.; Mourão Filho, F. A. A. 2007. Diagnosis and recommendation integrated system norms, sufficiency range, and nutritional evaluation of Arabian coffee in two sampling periods. Journal of Plant Nutrition. 30(10): 1651-1667. DOI: $10.1080 / 01904160701615525$

31. Partelli, F. L.; Vieira, H. D.; Silva, M. G.; Ramalho, J. C. 2010. Seasonal vegetative growth of different age branches of conilon coffee tree. Semina: Ciências Agrárias. 31(3): 619-626. DOI: 10.5433/1679-0359.2010v31n3p619

32. Partelli, F. L.; Marré, W. B.; Falqueto, A. R.; Vieira, H. D.; Cavatti, P. C. 2013. Seasonal vegetative growth in genotypes of Coffea canephora, as related to climatic factors. Journal of Agricultural Science. 5(8): 108-116. DOI: 10.5539/jas.v5n8p108

33. Partelli, F. L.; Espindula, M. C.; Marré, W. B.; Vieira, H. D. 2014. Dry matter and macronutrient accumulation in fruits of conilon coffee with different ripening cycles. Revista Brasileira de Ciência do Solo. 38(1): 214-222. DOI: 10.1590/S0100-06832014000100021

34. Partelli, F. L.; Gomes, W. R.; Oliveira, M. G.; Dias, J. R. M.; Espindula, M. C. 2016. Normas foliares e diagnóstico nutricional do cafeeiro na pré-florada e granação, no Espírito Santo. Coffee Science. 11(4): 544-554. DOI: 10.25186/cs.v11i4.1177 
35. Partelli, F. L.; Oliveira, M. G.; Covre, A. M.; Vieira, H. D.; Dias, J. R. M.; Braun, H. 2018. Nutritional standards and nutritional diagnosis of the Conilon coffee plants in phenological growth stages. Journal of Plant Nutrition. 41(19): 1-11. DOI: 10.1080/01904167.2018.1510513

36. Partelli, F. L.; Golynski, A.; Ferreira, A.; Martins, M. Q.; Mauri, A. L.; Ramalho, J. C.; Vieira, H. D. 2019. Andina - first clonal cultivar of high-altitude conilon coffee. Crop Breeding and Applied Biotechnology. 19(4): 476-480. DOI: 10.1590/1984-70332019v19n4c68

37. Partelli, F. L.; Giles, J. A. D.; Oliosi, G.; Covre. A. M.; Ferreira, A.; Rodrigues, V. M. 2020. Tributun: a coffee cultivar developed inpartnership with farmers. Crop Breeding and Applied Biotechnology. 20(2): e30002025. DOI: 10.1590/198470332020v20n1c21

38. Santos, H. G.; Jacomine, P. K. T.; Anjos, L. H. C.; Oliveira, V. A.; Lumbreras, J. F.; Coelho, M. R.; Almeida, J. A.; Araujo Filho, J. C.; Oliveira, J. B.; Cunha, T. J. F. 2018. Sistema brasileiro de classificação de solos ( $5^{\text {nd }}$ ed.). Brasília, DF: Embrapa.

39. Silva, F. C. 2009. Manual de análises químicas de solos, plantas e fertilizantes ( $2^{\text {nd }}$ ed.). Brasília: Embrapa Informação Tecnológica. Rio de Janeiro: Embrapa Solos.

40. Singh, D. 1981. The relative importance of characters affecting genetic divergence. The Indian Journal of Genetics and Plant Breeding. 41: 237-245.

41. Starling, L. C.T.; Martins, L. D.; Rodrigues, W. N.; Reinicke, T. M.; Colodetti, T. V.; Amaral, J.F.T.; Partelli, F. L.; Tomaz, M. A.; Espindula, M. C. 2019. Genetic diversity in nutritional parameters in response to drought of Coffea canephora cultivated in Rondonia state, Brazil. Genetics and Molecular Research. 18(2): 1-12. DOI: 10.4238/gmr18300

42. Taiz, L.; Zeiger, E.; Møller, I. M.; Murphy, A. 2015. Plant physiology and development (6 ${ }^{\text {nd }}$ ed.). New York: Sinauer Associates.

\section{ACKNOWLEDGMENTS}

The authors wish to thank the first breeders, i.e., the farmers who performed the initial selection of most superior genotypes available nowadays and the sir farmer Thekson Pianissoli. The Universidade Federal do Espírito Santo - UFES for funding this investigation for providing experimental resources; the Fundação de Amparo à Pesquisa e Inovação do Espírito Santo - FAPES (grants $\mathrm{n}^{\circ}$. 84320893); the Conselho Nacional de Desenvolvimento Científico e Tecnológico - CNPq (grants n ${ }^{\circ} .420789 / 2016-2$ and no. 304687/2017-0) and the Coordenação de Aperfeiçoamento de Pessoal de Nível Superior - CAPES (Finance Code 001). 